\title{
ОБУЧЕНИЕ РАССКАЗЫВАНИЮ ПО ДЕТСКИМ РИСУНКАМ СТАРШИХ ДОШКОЛЬНИКОВ С РЕЧЕВЫМ НЕДОРАЗВИТИЕМ
}

\author{
Крикунова Любовь Васильевна \\ МДОУ № 25
}

\begin{abstract}
Аннотация: Данная статья раскрывает вариант подхода к работе, направленной на развитие связной монологической речи дошкольников, имеющих сложные речевые отклонения. Особенность подхода заключается в сочетании изобразительной и речевой деятельности, когда ребенку предлагают создать рисунок и составить рассказ по нему. Сочетание активной изобразительной и речевой деятельности имеет широкие горизонты положительного взаимного влияния в развитии ребенка.
\end{abstract}

Ключевые слова: обучение дошкольников, монологическая речь, рассказ, речевое недоразвитие, эффективность.

\section{TEACHING STORYTELLING BASED ON CHILDREN'S DRAWINGS OF OLDER PRESCHOOLERS WITH SPEECH UNDERDEVELOPMENT}

Krikunova Lyubov Vasilyevna

\begin{abstract}
This article reveals a variant of the approach to work aimed at the development of coherent monological speech of preschoolers with complex speech deviations. The peculiarity of the approach is a combination of visual and speech activity, when a child is offered to create a drawing and compose a story based on it. The combination of active visual and speech activity has wide horizons of positive mutual influence in the development of the child.

Key words: preschool education, monologue speech, story, speech underdevelopment, efficiency.

Успешность школьного обучения детей во многом зависит от уровня овладения ими речью. Адекватное восприятие и воспроизведение текстовых учебных материалов, умение самостоятельно выстраивать и излагать свои суждения - учебные действия, которые требуют достаточного уровня развития понимания речи, владения языковыми и коммуникативными компетенциями.
\end{abstract}


Наибольшие трудности проявляются при необходимости выстраивания монологических высказываний.

В современных психологических и педагогических исследованиях отмечается, что умения и навыки связной речи при спонтанном их развитии не достигают того уровня, который необходим для полноценного обучения ребенка в школе.

Сложность овладения связной монологической речью детьми старшего дошкольного возраста, по мнению В.К. Воробьевой, связана с тем, что для ее понимания и создания недостаточно накопленного сенсорного опыта. Необходима активная интеллектуальная работа, направленная на выделение существенных признаков предмета. Кроме того, внутренняя, смысловая организация такого связного сообщения не имеет «жесткой» программы. Она носит условный, субъективный характер и зависит от последовательности выделения качеств предмета в зависимости от целей коммуникации. Дети с недоразвитием речи испытывают серьезные затруднения при языковом оформлении связных высказываний [1, с. 37]. Учитывая стабильно высокий процент обучающихся, имеющих различные формы речевой патологии, становится очевидным факт, что умениям и навыкам монологического высказывания нужно обучать специально. Поэтому, одной из важных сторон воспитания детей дошкольного возраста становится формирование умения составлять разные виды рассказа, пересказ, описание событий, явлений $[2$, c. 25$]$.

Поиск эффективных путей в этой работе, вызвал необходимость создания модели обучения рассказыванию, в которой формирование мотивационного аспекта и реализация активной игровой деятельности ребенка проявились бы наиболее полно.

Опыт наблюдений за воспитанниками показал, что когда дошкольники рисуют, то зачастую проживают целые истории из опыта или вымышленные. Это обусловило идею о том, что собственные рисунки детей являются прекрасным мотивом, стимулом и ассоциативной базой для составления рассказов. Поэтому мы включили и активно использовали в течение ряда лет эту форму формирования связной монологической речи, а именно, обучение составлению рассказов по собственным рисункам детей. Работа представляла собой последовательную смену изобразительной и речевой деятельности или их сочетание. 
Одним из самых простых вариантов устного изложения принято считать рассказ-описание. На начальных этапах вводили простые описательные рассказы с опорой на наглядный или словесный план, помогали, направляли вопросами, уточнениями. Дети овладевали описательным рассказом по плану, предложенному педагогом. Для повышения мотивации детей предлагали описать близких людей: маму, папу, бабушку, дедушку по следам изобразительной деятельности. Традиционно в ноябре проходит День Матери, и к этому празднику предлагали детям нарисовать маме ее портрет в подарок. Далее просили дополнить рисунок рассказом о маме, чтобы подарок стал более полным и ценным. Рассказ ребенка фиксировали и подклеивается к портрету. Описывая мамочку, ребенок особенно старался, подбирал красивые точные слова и сравнения, пожелания, проявлял высокую эмоциональную заинтересованность, в результате чего рассказы обычно получались очень трогательными и интересными. Во избежание повторов детьми друг за другом, на начальных этапах работа проводилась только индивидуально. Готовыми работами (рисунками с рассказами) мы украшали зал к празднику, а после утренника, дети вручали их в качестве подарков. Подобным образом, готовили подарки папам в День Защитника Отечества. Родители принимали такой подарок ребенка с душевной теплотой, признавались, что хранят в семейных архивах, цитируют детские повествования родственникам. Это повышало значимость рассказа в глазах ребенка, желание повторить ситуацию успеха, проявить коммуникативную инициативу.

Постепенно рассказы детей становились более самостоятельными, развернутыми, насыщенными и обогащенными лексико-грамматическими средствами.

В качестве усложненной формы создания описательного рассказа предлагали дошкольникам нарисовать семью и описать ее. Предлагали устные вопросы для построения последовательности рассказывания:

- Какая у меня семья? (У меня добрая, любящая, заботливая семья);

- К Ко живет в моей семье? (Перечислить членов семьи, кто кому кем приходится);

- К Кто чем занят? (Работа, учеба, любимые занятия членов семьи);

- Что мы делаем вместе?

Давали установку, что в рассказе непременно должны присутствовать красивые слова-признаки, интересные сравнения. На момент включения в работу такого вида устного изложения у детей заметно повышались речевые 
умения, поэтому считали целесообразным использовать подгрупповые и фронтальные формы занятий. Повторов удавалось избежать в силу того, что каждый ребенок хотел рассказать именно о своей семье, говорил эмоционально, с теплотой. Другие дети внимательно, заинтересовано слушали. Научить слушать обращенную речь - это также важная задача в работе логопеда. Помимо этого, дети получали возможность анализировать рассказы товарищей и учились друг у друга. Например, один мальчик так расчувствовался, рассказывая о своей семье, что использовал следующее выражение: "...но моя главная награда, - это когда мы всей своей дружной семьей гуляем после парада на набережной, разговариваем, смеемся, смотрим на реку". Через пару дней мы спросили у ребенка, чтобы закрепить это выражение: "Помнишь, какими красивыми словами ты закончил свой рассказ о семье?" Его ответ опередили другие ребята, с удовольствием повторили это выражение - "моя главная награда". Таким образом, дети перенимали друг у друга эпитеты, сравнения, красивые признаки, точные денотаты.

Прекрасной темой для рисунков и рассказов по ним является прошлый опыт детей. Например, выходной день или праздник в кругу семьи: масленица, день рождения, 9 мая. Создание таких тематических рисунков и составление рассказов по ним предлагали выполнить родителям с детьми в качестве домашнего задания.

Включали рассказы из личного опыта детей в свою работу. Очень интересными получались продукты детской деятельности на тему "Я и мама улыбаемся". Сначала ребенок рисовал соответствующий парный портрет, а затем рассказывал, почему они с мамой улыбаются. Большинство ребят вспоминают приятные или смешные моменты жизни. Например, мальчик рассказал, как они учились кататься на роликах. Но иногда, и это весьма трогательно, дети рассказывали, что улыбаются просто от того, что они с мамой любят друг друга. И это также превращалось в интересную, поучительную, душевную историю.

Ввели в свою работу следующий прием. В день рождения одного из детей группы предлагали ребятам нарисовать для именинника подарок или портрет и сказать комплементы, поздравления, пожелания. Высказывания пропечатывали на обратной стороне рисунков. Ребенок, отмечающий день рождения, мог нарисовать угощения и развлечения для друзей. Когда все работы готовы, из них собирали поздравительный альбом, который дошкольники дарили имениннику. Это было очень трогательно и ценно для 
детей, в том числе, в плане формирования речевых умений, активного коммуникативного поведения.

Самым сложным видом связной монологической речи является творческое рассказывание [3, с. 259]. Обучению творческому рассказыванию, основанному на детской фантазии, очень помогает активная изобразительная деятельность. На заключительном этапе логопедического сопровождения стало возможным предлагать ребятам творческое рисование и рассказывание. Темы предлагали разнообразные: дом мечты для моей семьи, морское путешествие, космическое приключение. В процессе рисования у ребенка разворачивалась сложная интересная история, а сам рисунок служил ее отражением, иллюстрацией.

Готовые рисунки и рассказы детей подклеивали в индивидуальные тетради и сохраняли до момента окончания детского сада.

Опыт показал, что составление рассказов по собственным рисункам способствует формированию речевой компетентности, обеспечивает развитие связной монологической речи, в том числе творческой. Повышает коммуникативную мотивацию и инициативу детей с тяжелыми формами речевой патологии. Реализация модели обучения рассказыванию по собственным рисункам обеспечивает большую эффективность коррекционнологопедической работы по развитию связной речи за счет взаимодополняющего взаимодействия речевой и изобразительной деятельности в процессе коррекционно-логопедической работы.

\section{Список литературы}

1. Воробьева В.К. Методика развития связной речи у детей с системным недоразвитием речи: учеб. пособие / В.К. Воробьева. - М.: АСТ: Астрель : Транзиткнига, 2006. - 158[2] с.

2. Выявление и преодоление речевых нарушений в дошкольном возрасте: методическое пособие / Составитель И.Ю. Кондратенко. - М.: Айрис-Пресс, 2005. - 224 с.

3. Глухов В.П. Комплексный подход к формированию связной речи у детей дошкольного возраста с нарушениями речевого и познавательного развития: Монография. - Изд. 2-е, исправ. и перераб. - М.: В. Секачев, 2014. $537 \mathrm{c}$. 